Volume 3 Nomor 2, Halaman 30-37, Juli-Desember 2016

RISTEKDIK | Jurnal Bimbingan dan Konseling

P-ISSN: 2527-4244, E-ISSN : 2541-206X

\title{
IMPLEMENTATION GUIDANCE SERVICES GROUP LEARNING DIFFICULTIES TO OVERCOME
}

\author{
Asmaryadi \\ Universitas Muhammadiyah Tapanuli Selatan \\ Email: asmaryadi@um-tapsel.ac.id
}

abstrak

This study is based on problems that overcome learning difficulties. The research goal is to obtain a picture of the decline of learning kesultian sisw in SMA 1 Padangsidimpuan memalui group counseling services. The method used in this research is True experimental design with pretest$\neg$ Posttest shape control group design. with samples of the experimental class is the first class XI IPS as many as 10 students and the control class is class XI IPS II as many as 10 students so that the total sample of 20 students. Group counseling services are conducted twice meetings and two meetings of information services, namely in the first meeting perform pretest and posttest perform all treatments. Data were analyzed using the Wilcoxon rank test signesd and Kolmogorov Smirnov 2 with the help SPSS version 20.00. From the results of the implementation is done, a significant increase is mainly posttest experiment. The findings in the experimental group and the control group there were significant increases between the posttest and posttest control experiment. On average variable learning difficulties at 143. 6000 (posttest experiment) while the control group 117.4000 (posttest control) looks very significant difference. The conclusion of this study the data processing, shows that the implementation of group counseling services can overcome learning difficulties. It is recommended for teachers to students' learning difficulties is much decreased, and a much better way of learning and implementing the spirit of learning more so that there is no learning difficulties. For further research, is expected to make a research on other learning difficulties in order to assist students in improving ways of learning through other methods.

Keywords: Guidance Services Group, Learning Difficulti

\section{PENDAHULUAN}

Menurut M. Dalyono (2012: 229)

kesulitan belajar adalah dalam keadaan dimana anak didik atau siswa tidak dapat belajar sebagaimana mestinya. Ketidak sanggupan penyelesaian akan menimbulkan ketegangan bagi tersebut akan dapat mendorong siswa berprilaku siswa itu sendiri. Jika ia tidak dapat lagi yang tidak dapat menyesuaikan diri yang dapat menghadapi ketegangan tersebut, ia akan mencari melemahkan motivasinya dalam belajar dan jalan keluar atau penyelesaian. Mencari bahkan dapat berdampak sebagai berikut:

1. Siswa yang bersangkutan mengalami hal-hal lain. Masalah seolah-olah terselesaikan kesulitan dalam belajarnya prestasinya pada hal sesungguhnya hanya tertekan pada akan menurun dan mengalami kegagalan. lapisan taksadar, dan tanpa disadari justru

2. Siswa yang bersangkutan mengalami menimbulkan masalah baru yang semakin berat. kesulitan dengan lingkungan sosialnya, ia merasa minder dari teman-teman fenomena yang terjadi di sekolah maka penulis bergaulnya, merasa dikucilkan teman, mengidentifikasikan masalah sebagai berikut ; penampilan yang kurang menarik dan 1. Munculnya kelainan prilaku siswa seperti mengambil sikap mengasingkan diri baik di lingkungan masyarakat maupun lingkungan sekolah tempat ia belajar.

Masalah siswa yang tidak mendapat Berdasarkan latar belakang di atas, serta kesukaan berteriak-teriak dan ribut di dalam kelas 
2. Mengusik teman

3. Berkelahi

4. Sering tidak masuk sekolah

5. Rendahnya kapasitas intelektual/inteligensi siswa

6. Lingkungan keluarga

7. Belum terlaksananya bimbingan kelompok secara maksimal

\section{METODOLOGI}

Jenis penelitian yang dilaksanakan adalah penelitian kuantitatif dengan menggunakan metode eksperimen. Eksperimen adalah suatu cara untuk mencari hubungan sebab akibat (hubungan kausal) antara dua faktor yang sengaja ditimbulkan oleh peneliti dengan mengeliminas atau menyisihkan faktor-faktor lain yang mengganggu.

Peneliti dituntut untuk memanipulasi dan mengendalikan satu atau lebih variabel bebas saat mengamati variabel terikat untuk melihat perbedaan sesuai dengan manipulasi variabel bebas tersebut atau metode penelitian yang melihat hubungan sebab akibat kepada dua atau lebih variabel dengan memberi perlakuan lebih pada kelompok eksperimen. Penelitian ini menggunakan desain kelompok non ekuivalen (untreated control group design with pretest and postest)

Tabel. 1

Penelitian eksperimen dengan desain kelompok non ekuivalen:

\begin{tabular}{|c|c|c|c|}
\hline Kelompok & Pretest & Treatment & Postest \\
\hline Eksperimen & $\mathrm{O}_{1}$ & $\mathrm{X}$ & $\mathrm{O}_{2}$ \\
\hline Kontrol & $\mathrm{O}_{3}$ & - & $\mathrm{O}_{4}$ \\
\hline
\end{tabular}

\section{a. Populasi}

Sugiyono (2008:118) Populasi adalah wilayah generalisasi yang terdiri atas obyek, subyek yang mempunyai kualitas dan karakteristik tertentu yang ditetapkan oleh

peneliti untuk di pelajari dan kemudian ditarik kesimpulannya. Adapun populasi dari penelitian ini adalah seluruh siswa kelas XI IPS SMA an Negeri 1 Padangsidimpuan yang terdiri dari dua kelas, yaitu kelas XI IPS 1 dan kelas XI IPS 2 yang berjumlah 62 siswa.

Tabel. 2

Populasi

\begin{tabular}{|c|c|c|c|c|}
\hline \multirow{2}{*}{ No } & \multirow{2}{*}{ Kelas } & $\begin{array}{c}|c| \\
\text { Pumlah Siswa }\end{array}$ & \multirow{2}{*}{ Total Siswa } \\
\cline { 3 - 4 } & & $\mathbf{n}$ & Laki-laki & \\
\hline $\mathbf{1}$ & XI IPS 1 & 19 & 12 & 31 \\
\hline $\mathbf{2}$ & XI IPS 2 & 21 & 10 & 31 \\
\hline \multicolumn{4}{|c|}{ TOTAL } & $\mathbf{6 2}$ \\
\hline
\end{tabular}

\section{b. Sampel}

Menurut Suharsimi A. (2006:120)

Menjelaskan pengertian sampel penelitian ini adalah sebagian atau wakil dari keseluruhan (jumlah) yang akan diteliti.

Berdasarkan hasil dari Cluster Sampling (Area Sampling) Kelas XI IPS-1 Berjumlah 10 orang terpilih sebagai kelas eksperimen dan kelas XI IPS-2 berjumlah 10 orang sebagai kelas kontrol.

Tabel. 3

\section{Sampel}

\begin{tabular}{|c|c|c|c|c|}
\hline \multirow{2}{*}{ No } & \multirow{2}{*}{ Kelas } & \multicolumn{2}{|c|}{ Jumlah Siswa } & \multirow{2}{*}{ Total Siswa } \\
\cline { 3 - 4 } & & Perempuan & Laki-laki & \\
\hline $\mathbf{1}$ & XI IPS 1 & 5 & 5 & 10 \\
\hline $\mathbf{2}$ & XI IPS 2 & 5 & 5 & 10 \\
\hline \multicolumn{3}{|c|}{ TOTAL } & $\mathbf{2 0}$ \\
\hline
\end{tabular}

\section{c. Teknik Pengumpulan Data}

Penulis mengggunakan alat pengumpulan data adalah dengan menyebarkan angket kepada siswa yang berkesulitan belajar di SMA Negeri 1 Padangsidimpuan dengan membubuhkan jawaban singkat responden meletakkan tanda ceklist $(\sqrt{ })$ pada kemungkinan pernyataan yang benar dengan 35 item soal pernyataan.

\section{d. Teknik Analisis Data}


Teknik analisis statistik non-parametric perhitungan daftar perhitungan angket kesulitan yang digunakan untuk menguji dalam penelitian belajar.

ini adalah uji jenjang bertanda Wilcoxon Signed Berdasarkan data yang diperoleh, maka dapat Raks Test dan metode Kolmogorov Smirnov 2- dideskripsikan hasil penelitian sebelum dilakukan Independent Samples bagi kelompok sampel perlakuan (pretest) dan setelah diberikan anda, pengujian hipotesis dengan cara uji jenjang perlakuan (posttest), dimana pengolahan data bertanda dilakukan apabila ingin memastikan kuantitatif dilakukan dengan menggunakan tentang ada atau tidaknya perbedaan kondisi bantuan SPSS Versi 20.00 for windows. setelah perlakukan tertentu diberikan.

Kemudian metode Kolmogorov Smirnov 2Independent Samples bagi kelompok sampel ganda dititik beratkan pada upaya menguji validitas hipotesis nihil yang menyatakan kelompok sampel pertama dan kedua berasal dari populasi yang identik.

Oleh karena itu maka metode analisis data yang dilakukan dalam penelitian ini dijabarkan sebagai berikut:

1. Untuk mendeskripsikan perbedaan kesulitan belajar siswa sebelum dan sesudah diberikan perlakuan baik kelompok eksperimen (perlakuan layanan bimbingan kelompok) maupun kelompok kontrol (perlakuan layanan informasi). Peneliti menggunakan analisis data dengan teknik Wilcoxon signed rank test dengan bantuan program SPSS versi 20.00. Analisis ini untuk menguji hipotesis nomor 1 dan 2.

2. Untuk menguji hipotesis kesulitan belajar siswa setelah diberikan perlakuan pada kelompok eksperimen (layanan bimbingan kelompok), dengan siswa kelompok kontrol (konvensional layanan informasi) digunakan teknik Kolmogorov Smirnov 2-Independent Samples dengan bantuan program SPSS versi 20.00. Analisis ini untuk menguji hipotesis nomor 3 .

\section{HASIL}

\begin{tabular}{|c|c|c|c|c|c|}
\hline & \multirow[b]{2}{*}{ INDIKATOR } & \multicolumn{2}{|c|}{$\begin{array}{c}\text { Kelas } \\
\text { Eksperimen }\end{array}$} & \multicolumn{2}{|c|}{ Kontrol } \\
\hline & & $\begin{array}{l}\text { Pre } \\
\text { Test }\end{array}$ & $\begin{array}{c}\text { Post } \\
\text { Test }\end{array}$ & $\begin{array}{l}\text { Pre } \\
\text { Test }\end{array}$ & $\begin{array}{c}\text { Post } \\
\text { Test }\end{array}$ \\
\hline $\begin{array}{l}\text { Faktor } \\
\text { Intern }\end{array}$ & $\begin{array}{ll}\text { 1. } & \text { Karena sakit } \\
\text { 2. } & \text { Karena kurang sehat } \\
\text { 3. } & \text { Cacat tubuh } \\
\text { 4. } & \text { Inteligensi } \\
\text { 5. } & \text { Bakat } \\
\text { 6. } & \text { Minat } \\
\text { 7. } & \text { Motivasi } \\
\text { 8. } & \text { Kesehatan mental } \\
\text { 9. } & \text { Tipe-tip khusus } \\
& \text { seorang pelajar. }\end{array}$ & $\begin{array}{l}86 \\
126 \\
83 \\
119 \\
39 \\
194 \\
180 \\
109 \\
32\end{array}$ & $\begin{array}{l}92 \\
140 \\
82 \\
134 \\
43 \\
218 \\
199 \\
129 \\
40\end{array}$ & $\begin{array}{l}77 \\
110 \\
60 \\
101 \\
38 \\
144 \\
118 \\
79 \\
23\end{array}$ & $\begin{array}{l}86 \\
122 \\
76 \\
111 \\
34 \\
176 \\
164 \\
96 \\
26\end{array}$ \\
\hline $\begin{array}{l}\text { Faktor } \\
\text { Ekstern }\end{array}$ & $\begin{array}{l}\text { 1. Faktor keluarga } \\
\text { 2. Faktor orangtua } \\
\text { 3. Suasana rumah atau } \\
\quad \text { keluarga } \\
\text { 4. Keadaan ekonomi } \\
\quad \text { keluarga } \\
\text { 5. Guru } \\
\text { 6. Faktor alat } \\
\text { 7. Kondisi gedung } \\
\text { 8. Kurikulum } \\
\text { 9. Waktu sekolah dan } \\
\text { disiplin kurang. }\end{array}$ & $\begin{array}{l}25 \\
54 \\
37 \\
31 \\
\\
26 \\
38 \\
26 \\
42 \\
28\end{array}$ & $\begin{array}{l}23 \\
53 \\
48 \\
42 \\
\\
41 \\
32 \\
45 \\
39 \\
46\end{array}$ & $\begin{array}{l}21 \\
63 \\
27 \\
25 \\
35 \\
33 \\
13 \\
22 \\
20\end{array}$ & $\begin{array}{l}25 \\
51 \\
32 \\
26 \\
25 \\
31 \\
30 \\
38 \\
36\end{array}$ \\
\hline & Jumlah & 1275 & 1446 & 1009 & 1185 \\
\hline
\end{tabular}

Hasil penelitian yang telah dilaksanakan pada siswa kelas XI SMA N 1 Padangsidimpuan sebanyak 20 orang sebagai sampel yang dibagi ke dalam kelompok kontrol sebanyak 10 orang yaitu kelas IX IPS 1 dan 10 orang kelompok eksperimen yaitu kelas IX IPS 2 berdasarkan

Tabel. 4

Perbandingan Hasil Penelitian Kesulitan Belajar 
Dari tabel di atas jika di lihat dari hasil memenuhi suatu kebutuhan yang dihayati perbandingan interval yaitu sebagai berikut :

bersama melalui penukaran dalam diskusi, atau untuk merencanakan suatu aksi yang akan dilaksanakan bersama.kemudian dapat diketahui melalui informasi yang diterima siswa melalui

Tabel. 5

Tabel perbandingan interval hasil

\begin{tabular}{|c|c|c|c|c|c|c|}
\hline \multirow{2}{*}{$\begin{array}{l}\mathrm{N} \\
\mathrm{o}\end{array}$} & \multirow{2}{*}{$\begin{array}{l}\text { Nilai } \\
\text { Interva } \\
1\end{array}$} & \multicolumn{2}{|c|}{ Eksperimen } & \multicolumn{2}{|c|}{ Kontrol } & \multirow{2}{*}{$\begin{array}{l}\text { Kategor } \\
\text { i }\end{array}$} \\
\hline & & $\begin{array}{l}\text { Pretes } \\
t\end{array}$ & $\begin{array}{l}\text { Posttes } \\
t\end{array}$ & $\begin{array}{l}\text { Pretes } \\
t\end{array}$ & $\begin{array}{l}\text { Posttes } \\
t\end{array}$ & \\
\hline 1. & $80-100$ & & 82 & & & $\begin{array}{l}\text { Sangat } \\
\text { Baik }\end{array}$ \\
\hline 2. & $70-79$ & 72 & & & & Baik \\
\hline 3. & $60-69$ & & & & 67 & Cukup \\
\hline 4. & $50-59$ & & & 52 & & Kurang \\
\hline 5. & $0-49$ & & & & & Gagal \\
\hline
\end{tabular}

Dilihat dari tabel di atas nilai perbandingan antara pretest-posttest kontrol bel dan prestest-posttest eksperiemen. Yang terjadi adalah nilai dari pretest-posttest eksperimen lebih tinggi dibandingkan prestest-posttest kontrol.

\section{PEMBAHASAN}

Hasil dari pengujian hipotesis diperoleh bahwa penurunan kesulitan belajar siswa dapat ditingkatkan dengan menggunakan layanan bimbingan kelompok. Sehingga terbukti bahwa pelaksanaan layanan bimbingan kelompok dapat mengatasi kesulitan belajar, selain dapat mengatasi kesultian belajar juga dapat meningkatkan belajar siswa. Peningkatan hasil pretest dan posttest disebabkan karena perlakuan layanan bimbingan kelompok yang diberikan oleh konselor.

\begin{tabular}{cccc}
\multicolumn{2}{c}{ Melalui } & layanan & bimbingan \\
kelompok, & siswa & merasakan & bebasnya
\end{tabular} menyampaikan pendapat, dapat mengembangkan perasaan, pikiran, persepsi, wawasan dan sikap yang menunjang tingkah laku untuk mengendalikan diri, tenggang rasa dan sumbang saran kepada sesama anggota kelompok.

Tenaga bimbingan memanfaatkan proses kelompok (group procces), yaitu interaksi dan komunikasi yang berlangsung antara anggota peserta kelompok yang bekerjasama untuk keigatan bimbingan kelompok yang diterima siswa melalui kegiatan bimbingan kelompok menjadi wawasan bagi mereka agar dapat menyusun rencana yang tepat khususnya dalam kesulitan belajar.

Setelah layanan bimbingan kelompok dengan kesulitan belajar siswa diberikan pada kelompok eksperimen, tingkat kesulitan belajar siswa semakin menurun. Hal ini dapat dilihat juga pada tabel dimana siswa yang semula memiliki kesulitan belajar yang baik $(72 \%)$ dan sangat baik (82\%). Sedangkan memiliki kesulitan belajar kurang (52\%) dan cukup (67\%). Meskipun mengalami semakin kesulitan belajarnya terjadi tidak sebaik penurunan yang terjadi pada kelompok eksperimen.

Sedangkan menurut pendapat $M$. Dalyono (2012: 229) "Kesulitan belajar adalah dalam keadaan dimana anak didik atau siswa tidak dapat belajar sebagaimana mestinya.

\section{KESIMPULAN}

Berdasarkan data hasil penelitian yang kemudian di lakukan analisis statistik dan uji hipotesis, maka dapat disimpulkan bahwa pelaksanaan bimbingan kelompok memiliki pengaruh yang signifikan dalam mengatasi kesulitan belajar siswa. Adapun kesimpulan umum penelitian ini adalah layanan bimbingan kelompok dan layanan informasi sama-sama efektif untuk mengatasi kesulitan belajar siswa, namun jika di bandingkan layanan bimbingan kelompok lebih efektif di bandingkan layanan informasi.

Secara khusus penelitian ini dapat disimpulkan (1) adanya perbedaan penurunan kesulitan belajar siswa pada kelompok eksperimen sebelum (pretest) dan sesudah (posttest) mengikuti kegiatan bimbingan kelompok dimana rata-rata $72 \%$ sebelum perlakuan (pretest) dengan kategori baik setelah 
mengikuti kegiatan bimbingan kelompok dimana rata rata $82 \%$ dengan kategori sangat baik dalam penurunan kesulitan belajar.

(2) terdapat perbedaan penurunan kesultian belajar siswa kelompok kontrol sebelum (pretest) dan sesudah (posttest) mengikuti kegiatan layanan informasi dengan rata rata $52 \%$ dan $67 \%$ dengan kategori cukup. (3) Terdapat perbedaan penurunan kesulitan belajar siswa kelompok eksperimen yang diberikan perlakuan layanan bimbingan kelompok dimana rata-rata mengemukakan pendapat siswa kelompok eksperimen lebih tinggi yaitu $82 \%$ dibandingkan rata-rata kelompok kontrol setelah diberikan perlakuan yaitu $67 \%$.

\section{DAFTAR PUSTAKA}

M. Dalyono. 2012. Psikologi Pendidikan. Jakarta: Rineka Cipta.

Suharsimi A. 2006. Prosedur Penelitian Suatu Pendekatan Praktik. Jakarta: Rineka Cipta.

Sugiyono. (2008). Metode Penelitian Pendidikan (Pendekatan Kuantitatif, Kualitatif, Dan $R \& D)$. Alfabeta 